\title{
Public Interest Opposite the Freedom of Contractual Will in Administrative Contracts in the Republic of Albania
}

Doi: 10.2478/ajis-2018-0026

\author{
PhD. Artan Spahiu \\ Lecturer at the "Law Department" \\ Faculty of Economy, \\ University of Elbasan "Aleksandër Xhuvani", Albania
}

\begin{abstract}
The protection of the public interest is the main principle governing the activity regulation of the administrative bodies. This activity, traditionally, has been developed through administrative acts, as an expression of the unilateral and authoritarian willpower of public authority, which creates legal consequences. The administrative act has been and remains the most important instrument for the administration bodies to accomplish their mission, but it is no longer effective. Particularly this lack of efficiency is noticed in recent years when the development of the economy and the needs of the evergrowing society have prompted the administration to adapt its activity by making use of other mechanisms "borrowed" from private law. An important part of public activity can also be achieved through the contract as a way that brings the state closer to the private, mitigating its dominant position and leaving space for the efficiency of private activity to fulfil public engagements. Such contracts today are known as "administrative contracts" or "public contracts". The terms mentioned above are instruments that establish legal relations, for the regulation of which the principle of public interest is opposed and competes with the principle of freedom of the contractual willpower. The regulation of these types of contracts is reached through the private law, which constitutes the general normative framework of contracts (lex generalis) even for the administrative contracts. But this general arrangement will have effect for as long as it does not contradict the imperative provisions of the specific act of public law (lex specialis), which regulates the administrative procedure for the completion of these contracts. This paper aims to bring to the spotlight the way our legislation predict and regulates administrative contracts, by emphasising particularly the features of their dualistic nature. The coexistence and competition of the principles of the freedom of contractual willpower and the protection of the public interest, evidenced in administrative contracts, is presented in this paper through the legal analysis of the Albanian legal framework which regulates these contracts. Under the terms when the role of the state in providing public services tends to increase and our legislation aims the harmonization in accord with the European legislation, it is necessary to improve the administrative contract regulation and extend its scope of action.
\end{abstract}

Keywords: administrative, public, contract, authority

\section{Introduction}

The new conditions for the development of the society have changed the way of exercising the administrative activity. When public administration, in the performance of its public activity, does not use the administrative act but concludes contracts, these are called administrative or public contracts, which have the characteristics of a private contract but at the same time aim to fulfil the general interest. Private law is used by the public administration because public law does not provide all the opportunities to achieve its objectives, while private law provides a wider scope in this direction ${ }^{1}$. To this end, the contractual structures may be adopted in public law, with the

\footnotetext{
${ }^{1}$ Sokol Sadushi, “E drejta administrative”, Tiranë 2005, Shtëpia Botuese ORA, pg.303,307.
} 
particularity that the contract is administrative, since it expresses the willpower and the authority of the administrative power ${ }^{2}$. Therefore, the administrative contracts are dualistic because at their essential they are contracts, but in the mean time they are administrative actions. For these contracts, the private law acts like a general fundamental right, as long as the public/administrative law does not regulate them ${ }^{3}$.

In Albania, only after the 1990s, was the way opened to the contemporaneous adjustment of the administrative contract. There were constitutional and legal changes that allowed the private property and the free enterprise ${ }^{4}$, as well as the right of the compensation in case of violation of the unlawful administrative acts ${ }^{5}$. Law No. 8485, dated 12.05.1999 "Administrative Procedure Code", was the one foreseeing for the first time the administrative contract, by giving two basic criteria in its definition: "Administrative contracts shall be those agreements, (a) where at least one of the parties is a body of public administration and (b) intending to create, amend or annul legal relations in the field of public law"6.

By that time, though there were legal arrangements of some types of contracts ${ }^{7}$ which today we call administrative, such a concept was unknown in our legislation and doctrine. According to the definition made by this $\operatorname{code}^{8}$, the activity of administrative bodies is the entirety of the acts and actions through which the willpower of the public administration is formed and manifested, as well as the execution of this willpower. The form of administrative activity regulated by this law, besides the administrative act, is the administrative contract as an agreement through which a legal relationship of public law is created, modified or extinguished ${ }^{9}$. The Code of Administrative Procedures of 1999, though vaguely, laid the foundations for a new understanding of the administration's activity, on the basis of a particular type of contract, such as the administrative one, and even listed the contracts that were called such $^{10}$.

\section{The Current Arrangement of Administrative Contracts in Albania}

The new Code of Administrative Procedures (abbreviation C.A.P) ${ }^{11}$ which came into force in 2016 gives us a more complete approach to this legal instrument. Initially, this law gives a similar definition to the old code for the administrative contract: "An administrative contract is an agreement that creates alters or extinguishes a concrete relationship under public law and in which at least one of the contracting parties is a public body"12.

The administrative contract, as currently adjusted, is foreseen as an instrument used by the public administration body to better fulfil its public functions, but it must naturally also respect the economic interests of the other party (private party) because in its essence it remains a contract. Thus, the law itself has taken care to incorporate the two basic pillars upon which administrative contracts are established, which are (a) the purpose of the contract for the realization of a public interest (public orientation of the contract) and (b) the non-violation of the interests or rights of third

\footnotetext{
${ }^{2}$ André de Laubadére, Yves Gaudemet, "Traite dë droit administratif, Tome 2, Paris 1996, Le photocopillage Tue Le Livre", pg.326.

${ }^{3}$ Law No.44/2015 "Code of Administrative Procedures of the Republic of Albania ", Article 124: "For the issues that are not explicitly regulated by this Code regarding the admistrative contract, shall apply the relevant provisions of the Civil Code of the Republic of Albania or of special legal forseening".

${ }^{4}$ Law No.7491, date.29.04.1991 "On the main constitutional provisions", article 10, 11, 12.

${ }^{5}$ Idem., article 14.

6Law No.8485, date.12.05.1999 "Code of Administrative Procedures", article 6.

${ }^{7}$ For example. Procurement, Auction and Concession Contract.

${ }^{8}$ Law No.8485, date.12.05.1999, article 2.

${ }^{9}$ Idem., article 151, paragraph 1.

${ }^{10}$ Idem., article 151, paragraph 2: "The following contracts are considered administrative: a) undertakings of the public works ; b) public works procurement; c) public service procurement; ç) licensing of gambling; d) continuous supply contracts; dh) contracting services of private entities in cases of natural disasters".

${ }^{11}$ Law No.44/2015, date 30.4.2015 "Administrative Procedure Code of the Republic of Albania".

12 Idem., article 3, paragraph 4.
} 
parties, as we are dealing with a contract (private orientation of the contract) ${ }^{13}$.

Also, the current regulation has increased the possibility for the public administration body to use the administrative contract, foreseeing the freedom of the administrative body to conclude this contract, enough to comply with certain conditions. These conditions, as foreseen by law ${ }^{14}$ in the form of insurmountable limits or borders are: a-the administrative contract can be concluded if the contract form is not expressly prohibited by law or does not contradict the itself nature of the administrative matter; and b-the administrative contract may be concluded if the public body is authorized by the law to decide on the matter with discretion. These two conditions must be fulfilled in a complementary way.

The connection of administrative contracts is foreseen, in special cases, by specific laws and this is due to the importance that this form of expressing the willpower of the public body, regulating the relations of that field, such as the law on public procurement, auctions and concessions ${ }^{15}$. In these cases, the conclusion of an administrative contract is always the product of an administrative procedure, such as a competition for the selection of the most successful contract operator. This administrative procedure, which is concluded with a contract, is implemented through administrative acts. So e.g. for the conclusion of a procurement or auction contract, it is necessary in advance to adopt a decision (administrative act) for the ranking of bids and for the announcement of the winning operator ${ }^{16}$.

Provisions of special laws are now generalized by the provisions of the Code of Administrative Procedure, which provides, that regardless of whether or not it is expressly provided for in a specific law, the public administration body may enter into an administrative contract if the above 2 conditions are met as provided for in article 119 of the Administrative Procedure Code. Moreover, according to the current regulation, the public body is free to choose whether to use the administrative act or the administrative contract to fulfil its public function but if it chooses to use the contract it is obliged in the body of the administrative contract to justify that the public interest is better protected by the signing of this contract ${ }^{17}$. Thus, the new code for the first time mentions the concept of a substitute administrative contract, foreseeing that the public administration body may conclude a substitute administrative contract with the party to whom an administrative act could present if the public interest is better achieved through the administrative contract ${ }^{18}$. The only limitation of this freedom is the need to always meet the two above-mentioned conditions ("the contract form is not explicitly prohibited by law" and "the public body is authorized to act discretionary"). This is a prediction that for the first time is part in the Albanian legal regulation and represents a very important step for the intensive application of administrative contracts.

According to C.A.P, administrative contracts are two-way contracts, in other words impose obligations and rights on both contracting parties, which are simultaneously debtors and creditors of each other. The other party, not a public body, is obliged to perform or not to perform an action or to give something against the conduct of an action by a public body ${ }^{19}$. In any case, this obligation assumed, serves to the public body for the fulfilment of an administrative public function, according to the purpose set out in the contract.

\section{Conditions of Validity and Causes of Cancellation of Administrative Contract}

The terms of validity of the administrative contract, due to its dual nature, must be sought at the same time in both laws that govern the private and public nature of the contract. Referring thus, in

\footnotetext{
${ }_{13}^{13}$ Idem., article 119, paragraph 1.

${ }^{14}$ Idem., article 119, paragraph 1, letter "a" and "b".

${ }^{15}$ Law No.9643, date 20.11.2006 "On Public Procurement", as amended; Law No.9874, date 14.2.2008 "On Public Auction", as amended; Law No. 9663, date 18.12.2006 "On Concessions", as amended;

${ }^{16}$ Law No.9643, date 20.11.2006, "On Public Procurement", as amended, article 58; Law No.9874, date 14.2.2008 "On Public Auction", as amended, article 39.

17 C.A.P., article 120, paragraph 3.

${ }^{18}$ Idem., article 120, paragraph 1.

${ }^{19}$ Idem., article 120, paragraph 2.
} 
an integrated manner to the provisions of the Civil Code ${ }^{20}$ and C.A.P ${ }^{21}$, the necessary conditions for the assignment and validity of the administrative contract result to be:

a. Free contract willpower, expressed, of the parties should not be wasted (defective). In the case of a public body, his free willpower shall be levied if exercised in violation of the law. It should not be forgotten that we are dealing with an administrative body which, to reach the signing of the contract, expresses its willpower through administrative acts, which should be valid. Absolute invalidity of any of these acts automatically leads to a lack of constitution of willpower by the contracting authority for entering into a contract with the other party, which affects the related contract.

b. The legal cause of the conclusion of the administrative contract should always be the provision of services, works and goods, in the public interest.

c. Object of the administrative contract must always be defined at the initial moment of an administrative proceeding ending with such a contract. In the case of public procurement, the object of the contract is defined in the administrative acts: the Procurement Order and the Contract Notice, which precedes the administrative procedure and should be made transparent (to be published) 22 .

d. Form of the administrative contract it should always be written, unless the law provides another specific form, such as, for example, contracts related to a notary act or electronic form. At this point, the provisions of the C.A.P stipulates that administrative contracts are always formal contracts, prevail over the Civil Code, which provides for other "liberal" forms of private contracts. Also, C.A.P is also rigorous in terms of signing the administrative contract, stipulating that this contract must be signed by the parties or representatives manually or electronically, in accordance with the modalities set out in the legislation in force. The signature on behalf of a public body is based on an authorization issued by the relevant body ${ }^{23}$.

e. The contract form is not explicitly prohibited by law or does not contradict the nature itself of the administrative matter; In fact, the ban on the signing of the administrative contract generally does not appear expressly in this form but rather in the form of imposing the issuance of an administrative act. As interpreted in this way, we conclude that the public administration body can not conclude administrative contracts when the issuance of an administrative act is an explicitly mandated legal obligation, so that the lawmaker obliges the body to fulfil its function only through an administrative act and not through the contract. It should be noted, therefore, that administrative contracts are invalid when a particular relationship in the field of public law cannot be regulated by contract but only by an administrative act (e.g. the employment of employees in the civil service $)^{24}$.

f. The public body is authorized by the law to decide on the issue with discretion. The discretion of the public body is the right of the above to exercise public authority to fulfil a legitimate aim in cases where the law partially foresees the modalities to achieve this, giving room for assessment of the election of the public body ${ }^{25}$. Discretion itself can be exercised legally when it is in compliance with the following conditions: a) it is provided by law; b) does not exceed the limits of the law; c) the election of a public body is done only to achieve the objective for which discretion is allowed and is in accordance with the general principles of this C.A.P; and; ç) the choice does not constitute an unjustified

${ }^{20}$ Civil Code, article 663.

${ }^{21}$ C.A.P., article 119, paragraph 1.

${ }^{22}$ CMD Nr.914, date 29.12.2014 "On approval of public procurement rules", as amended, article 5, 60 and 61/3.

${ }^{23}$ C.A.P, article 119, paragraphs 2 and 3.

${ }^{24}$ Sokol Sadushi, "E Drejta Administrative", Tiranë 2005, Shtëpia Botuese "ORA", pg.312, where it is mentioned the impossibility of appointing employees (civil servants) under contract, as the law expressly provides that such a thing is done only by an administrative act.

${ }^{25}$ C.A.P, article 3, paragraph 3. 
departure from previous decisions taken by the same body in the same or similar cases ${ }^{26}$.

\subsection{The invalidity of administrative contracts as a legal and administrative action.}

a. As legal action of the public administration body, the administrative contract can also be affected by the causes of the invalidity of legal actions. Thus, according to the provisions of the C.A.P, the invalidity of the administrative contract is governed by the provisions of the Civil Code which provide for the invalidity of legal action ${ }^{27}$. In that sense, the administrative contract will be absolutely or relatively invalid if it is in contravention with a law order, is committed to deceive the law, is made in the agreement of the parties without the intention to bring legal consequences (fictitious or simulated), when one of the parties has no capacity to act as and when the party has committed the legal act by being deceived, threatened, unloosens or because of the great need ${ }^{28}$.

Taking into consideration the manner of concluding the administrative contract and the parties participating in this contract, the decline in contravention of a provision of the law is exactly where the legal requirements governing the administrative procedures that precede the conclusion of an administrative contract have been violated. Thus, the law foresees regarding the invalidity of the administrative contract ex lege if the interests of third parties are violated by this contract in the form of non-compliance with the deadline and the administrative appeal procedure. For example, the Public Procurement Law provides that only non-compliance with the deadline for complaints by operators for the bid's evaluation procedures, as well as failure to comply with the appeal procedure, invalidates the related procurement contract ${ }^{29}$. Such a contract, concluded in the abovementioned conditions, is absolutely void because it is inconsistent with a provision of the law, in the sense of Article 92/a of the Civil Code, but also because the specific procurement law itself provides for such nullity. Therefore, the administrative procurement contract becomes absolutely invalid and this invalidity can be claimed at any time and by any interested subject solely because the contracting authority in the expressed willpower has not left the possibility of exhaustion of the possible administrative control of this willpower, by not giving to the third parties the opportunity to administratively appeal against the illegal actions of the administrative body. This invalidity can be claimed to be found in court, e.g. by each e-auction participant, since the above has a present interest in being the contractor of the administration.

The purpose of such a provision was, firstly, to ensure legality through the control of acts by which the contactor authority expresses his willpower at the administrative stage prior to the conclusion of the contract (which is wholly dominated by the rules and principles of administrative law) and secondly, it ensures the granting of the possibility of dissatisfied entities from this proceeding to complain about $\mathrm{it}^{30}$.

Under the terms when the contract is absolutely invalid, it should be considered as nonexistent, which means that the contracting party cannot, in such an administrative contract, benefit from the remuneration for the work performed under the terms of the contract. Regarding such a case, the Supreme Court ${ }^{31}$ stated in one of her decision: "The party

${ }^{26}$ Idem., article 11.

${ }^{27}$ Idem., article 122

${ }^{28}$ Civil Code, article 92 and 94.

${ }^{29}$ Law No.9643, date 20.11.2006, "On public procurement", as amended, article 58, point 6 "The assigment of the contract prior to the end of the notice of classification or before the administrative review has been completed, according to Chapter VII of this law, makes it absolutely invalid".

${ }^{30}$ Idem., Article 63/1: "Any person who has or has had an interest in a procurement procedure and when it has been damaged or threatened to be damaged by a decision of a contracting authority that is in contravention with this law, may appeal the decision".

${ }^{31}$ Decision of the Supreme Court No.822, date 12.05.2005 ("Curri" I.I.c vs. Ministry of Culture, Youth and Sports, with subject the obligated payment of additional work). 
cannot claim reward on the basis of a contract, as it is invalid, but may claim this reward on the basis of extra-contractual liability".

b. Also, as administrative action, the administrative contract is invalid even in cases when are not respected the two legal conditions for signing this contract, as provided in article 119, paragraph 1, letter "a" and "b" of the C.A.P (explained above), and when are not respected the requirements for concluding a substitute administrative contract ${ }^{32}$.

As we have said, the administrative contract is an administrative action because it is preceded by an administrative procedure to reach the signing of the contract. Consequently, in principle, the invalidity of administrative acts forming the contractual willpower affects the invalidity of the administrative contract. In regard to this, the doctrine further supports the thesis that distinguishes in these contracts two stages, the administrative procedure stage and the contracting stage, but the first affects the inefficiency of the second since the beginning. This is the latest verdict held by the Italian Court of Cassation ${ }^{33}$. Therefore, in the field of procurement, the absolute invalidity of administrative acts of the procurement phase can affect the validity of the procurement contract. If the contract is invalid, the administration is not obliged to execute it, but if it has allowed the execution, the private contracting entity must be rewarded and its financial interests should not be harmed. At the same time, precisely for the violations it has committed at the administrative stage, the contracting authority may be punished by paying the indemnity to any non-winner bidder.

\section{Dominance of One-Sided Public Authority's Willpower in the Administrative Contract Where he is a Party}

\subsection{The ability of the contracting public authority to unilaterally terminate the administrative} contract, if the public interest is violated.

The administrative contract is concluded at the conclusion of an administrative procedure, which is carried out through one-sided administrative acts through which the public administration forms and executes its contractor's willpower. It should be emphasized that, with the conclusion of the administrative contract, a new phase and that of the contractual relationship, regulated by civil law, begins for as long as it does not conflict with other more specific arrangements of public nature of these relations ${ }^{34}$. Therefore, the provisions of the Civil Code should be applied but with the change that the features of the administrative contract as administrative action will always have to be taken into consideration.

\footnotetext{
${ }^{32}$ C.A.P, article 122, paragraphs "a" and "b".

${ }^{33}$ In decision No.7481 date.27 March 2007 of the "Corte Civile di Cassazione" Italy, the court, among other things, has stated that: "The contract of entrepreneurship, given with the announcement of the winner, signed at a second phase, has no pure autonomy and does not constitute a source of rights and obligations between the parties, but has merely the value of a formal and reproductive act destined to incure flaws that represent the administrative procedure with which it is inseparably linked and falls immediately and automatically without the need for another decision, but only of a decision proving the invalidity of the administrative procedure. The judicial or administrative downturn, the acts of the forming phase, through which the present contractual willpower of the administration is formed, deprives the above mendtioned, with "ex tunc" effectively in legitimizing to negotiate. Substantially, the administrative body that has signed the contract, whenever ex tunc falls, one of the acts of the administrative procedure, which constitutes the willpower of the administration (such as the decision to contract, announcement or winner announcement) is in the conditions of the "in jure" signing, deprived from the legitimacy granted to it by administrative acts. The annulment of the essential phase of the winner announcement, marks in an overriding manner, the absence of one of the terms of the contract's validity, which, however, is private in terms of its legal effects".

${ }^{34}$ Law No.9643, date. 20.11.2006 "On public procurement", article 60(3): "Without prejudice to the provisions of this Law and any other provision applicable by the contracting authority, procurement contracts shall be governed by the provisions of the Civil Code".
} 
If we will narrowly assess the private aspect of the administrative contract, we must acknowledge that the parties cannot give up contractual obligations unilaterally without the consent of both parties. This is the general rule, except in the cases expressly provided in the law, when (a) the contract itself or the law allows unilateral withdrawal from the contract or (b) the termination of the contract is a sanction of non-performance by the other party. Thus, the Civil Code provides, strictly, a one-sided termination of a contract only in 2 cases, which, by nature, are covered by the administrative contract:

i- The right to withdraw from the contract unilaterally may be valid only if the parties expressly provide for such a right in the contract. The parties may also foresee for the payment of compensation against the opposite party towards whom the withdrawal is directed ${ }^{35}$. Such a provision of the Civil Code may be used in the case of administrative contracts, providing for the possibility of withdrawing a public party as a clause in the General Conditions of the Administrative Contract. Thus, procurement contracts can be envisaged as a general condition that the public administration body (the contracting authority) may withdraw from the contract implementation even after it has been concluded in the case when the public interest is proven to be affected in relation with this contract. It is understood that for this purpose the public administration body has to pay compensation to the other party because of this withdrawal, as it is presumed in good faith.

The right to withdraw from the contract unilaterally, according to the Civil Code, may be valid even if the law with a special provision provides for the right of one of the parties to withdraw from the contract even after it has begun to be implemented. In the case of an administrative contract, this right is generally, but explicitly provided by the provisions of the Code of Administrative Procedure (Article 123, paragraphs 2 and 3). According to this forecast, the public body may withdraw from the administrative contract unilaterally to avoid or stop the violation of the public interest. Such withdrawal must be made with an administrative act, written and reasoned, of the contracting authority, as well as compulsorily compensation for the damage caused to the other party. In this way, the foreseen of the Code of Administrative Procedures is not contradicted, but is in line with the provisions of the Civil Code.

ii- The termination of the contract may be conducted unilaterally from one party and also as a sanction of non-fulfilment of obligations from the other party ${ }^{36}$, if non-compliance is of such relevance as to justify the extreme extent of the termination of the contract unilaterally ${ }^{37}$. Even in this case, the public administration body may benefit from an administrative contract to terminate the contract unilaterally, claiming that the public interest has been violated, since the private party has not fulfilled the contract, which means that has not providing any public service. The termination of the contract in this case can be justified based on both the Civil Code (article 698) and the C.A.P (article 123). The particular in the administrative contracts is that the violation of the public interest allows the administration to terminate the contractual relationship at any moment without being necessarily linked to the fact of the execution or not of the contract by the other private party. This fact substantially distinguishes the administrative contract from private law contracts. A one-sided solution for public interest reasons constitutes a discretionary power to the administration that is known for all administrative contracts even if it is not provided in the terms of the contract.

\subsection{Possibility of unilateral amendment of the administrative contract by the contracting public body}

In special cases, the administration may change the size of the contract's object by adding or

\footnotetext{
${ }^{35}$ Civil Code, article 696.

${ }^{36}$ Civil Code, article 698: "In mutually agreed contracts, where one of the contracting parties fails to meet its obligations, the other contracting party, as the case may be, may require the fulfillment of the obligation or termination of the contract, except for compensation of the damages caused".

${ }^{37}$ Civil Code, article 699: "The contract can not be settled if the non-performance of the obligation by one of the parties is of little importance to the interests of the other party".
} 
reducing it, as unforeseen contingencies arises. Such a possibility is based on the requirements of public service, which is based on a very important principle, such as the continuity of public service, a principle which is not explicitly expressed in our legislation. Such a possibility exists in all administrative contracts, but is not unlimited for the administration. The change of the administrative contract must be such that it is in the interest of the functioning of the public service, but on the other hand, it should in no way affect the financial interests of the other contracting party ${ }^{38}$. The administration, in making these changes, is limited by law, for example, public procurements may be made up to $20 \%$ in additional work and further procurement procedures need to be developed. It may require the performance of an addendum, but up to this limit set by law, otherwise, the other party is not obliged to execute and may seek termination of the contract. Thus, C.A.P provides that if due to the circumstances revealed after the conclusion of the contract and unforeseeable at the time of its assignments, the continuation of the performance of contract obligations becomes very difficult for one of the contracting parties; they may agree to change or cancel the contract ${ }^{39}$.

A very important problem after the conclusion of the administrative contract is how a private contracting party can be protected if the public party (administrative body) interferes in this contract with unilaterally administrative acts. In regard to this case, judicial practice has maintained the position that the private party cannot protect its contractual rights by affecting the administrative act, but only by seeking the protection of the contractual relationship. So in a decision of his own, the Supreme Court ${ }^{40}$ has tatted that "Regardless of the content of the administrative acts, they are issued by the contracting authority and are compulsory for it, while for the other party they do not have any consequences, as their merger is regulated on the basis of the respective contract and each party, for what the claim might be, can address to the court to protect the rights alleged as violated in the contract. Under these conditions, the private party is not legitimized to defend its alleged rights by seeking the annulment of the administrative acts of the contracting authority, which, if they affect the contingency provisions, the protection of rights should have been made on the basis of legal protection of the contractual merger. As a matter of principle, administrative acts may be necessary for the connection of contractual relations, and then upon the conclusion of contractual relations, the respective disputes between the parties will be resolved on the basis of legal requirements, regulating the respective contractual relations...".

\subsection{Limited capacity of the public body to negotiate in administrative contracts}

It should first be acknowledged that the public administration is deprived of contractual freedom and is not able to base its rights and obligations solely on its free willpower; hence it is not characterized by the autonomy of the private willpower and contract freedom. Its activity to conduct an administrative contract is under the influence of the permitted powers by law and to the extent that it determines. Otherwise, the contract would be invalid because it would be in contravention to the law. Therefore we say that in administrative contracts, the public body has no negotiating autonomy or this autonomy is quite limited.

This restriction is noticed in the fact that the public administration is not free in the choice of the other contracting party, as the above is elected by competitive and equal procedures between the bidding candidates, where operate the principles and rules of administrative law. Also, the restriction is noticed in the impossibility of the public administration body to set the terms of the administrative contract completely freely, which in some cases implies the imposition of the general conditions of the contract as standard models previously approved by the competent authorities ${ }^{41}$.

${ }^{38}$ C.A.P, article 119, paragraph 1: "The public body, for the realization of a public interest to which it serves but without prejudice to the interests or rights of third parties, may conclude an administrative contract..."

${ }^{39}$ Idem., article123, paragraph 1.

${ }^{40}$ Decision of the Supreme Court No.513, date 11.03.2003 ("Arberi" I.I.c vs. Municipality of Ballsh, with the subject of revocation of administrative act).

${ }^{41}$ For example: General Terms of Contract, adopted through Standard e-Auction Documents, drafted, approved and made public by PPA (www.app.gov.al). 
Moreover, the willpower expressed by the administration in the choice of the contractor will be subject to administrative control through appeal ${ }^{42}$, or mainly ${ }^{43}$, in order to verify the implementation of the legal provisions that authorize the administration to make this selection. However, the contract cannot be entered if it is not possible to control the willpower of the administration on an administrative basis and if it is signed, under these conditions, it is invalid.

Regarding the capacity for the negotiation of the administration, broadly exist the idea that in the category of defects of legitimating to contact, are included of all those defects, other than the lack of legal capacity and that to act, from which derives the ability of the subject to be official of subjective rights and to perform the functions effectively and efficiently ${ }^{44}$. The willpower expressed by the administration in the choice of contractor (the will expressed through administrative acts) must be legal; otherwise the shortcomings of pre-contractual acts are translated into defects of the negotiating capacity of the administration. If the administrative act of selecting the contractor is invalid, this means that the willpower of the administration to choice the other contracting party is invalid and this has an impact on the contract, as the administrative body is in the conditions where it has contracted without the necessary legitimacy.

\section{The Possibility of a Third Party to Impinge the Administrative Contract}

The violation of the interests of a third party may become the cause of the disruption of the administrative contract, in some way, which is analysed as follows:

i. If the damaged party requests the public administration body to withdraw from the contract due to a violation of the law, the above may decide to withdraw from this contract that is related to the third party's interest if you consider it a violation of the public interest. The unilateral withdrawal from the administrative contract, in order to avoid the violation of the public interest, as mentioned above, is provided by the provisions of the C.A.P. ${ }^{45}$.

ii. The third person to whom the interests have been violated may require the administrative court to repeal the administrative act through which the public administration body has decided to enter into an administrative contract. Thus, the third affected entity, who claims to be a winner, in the case of the procedures for concluding a procurement contract, concession, or $\mathrm{PPP}^{46}$, may require the abrogation as absolutely void of the administrative act by which the administrative body has concluded the contract signing. The repeal of this act should oblige the administrative body to break the administrative contract in agreement with the other contracting party, or to withdraw unilaterally from the administrative contract, as we are in the conditions when the will of the public body is overthrown. This conclusion is a consequence of considering the administrative contract as an administrative act. If the administrative body fails to do so (does not break the contract in agreement with the other party or does not withdraw from it unilaterally), then the third person, who has abolished in court the administrative act of creation of the willpower of the public body, may seek compensation for the signing of an administrative contract which has violated his legitimate rights.

iii. A third person, as a rule, can not seek direct court termination of an administrative contract, concluded between an administrative body and another entity, due to the action

\footnotetext{
${ }^{42}$ For example: The control exercised by the Public Procurement Commission (CPC), which is the highest procurement body reviewing complaints about procurement procedures, ... The CPC, at the conclusion of the review of complaints, makes decisions which are administratively final (article 19/1 of the CCP).

${ }^{43}$ For example:, Verification for the implementation of public procurement procedures, after the phase of signing the procurement contract done by the Public Procurement Agency (PPA), article 13 of the CCP.

${ }^{44}$ Nicola Durante, "Arresti giurisprudenziali in tema di annullamento dell'aggiudicazione ed effetti sul contratto medio tempore stipulato".

${ }^{45}$ C.A.P, article 123/2: "The public body may withdraw from the administrative contract unilaterally to avoid or to stop the violation of the public interest".

${ }^{46}$ Law no.125/2013 "On concessions and private public partnership".
} 
of the principles of private law. Thus, in principle, the court can not resolve the conclusion of a contract concluded between the two parties, if such a request is not directed by one of the parties of the contract. But if the absolute invalidity of the administrative contract is foreseen by the specific law itself, because of the violation of the mandatory provisions, then a third party (not party to the contract) may seek its nullity. Such is the case of the procurement contract, which is qualified by the law itself as absolutely invalid if it has been concluded without respecting the deadline and procedures of administrative appeal.

If we refer to the legal framework regulating the activity of an administrative court, which limits the types of lawsuits that may arise, we should say that the third person, affected by the administrative contract, may request separately, or jointly:

a. ascertainment of the illegality of the administrative action (in other words of the administrative contract) that no longer produces legal consequences for the plaintiff, since it is already signed between the two parties, always if the plaintiff has a reasonable interest in this; and

b. the accuracy of the rights and obligations between the plaintiff and the public body, in other words, the determination of the compensation that the administrative body has to pay, or other actions which he has to take in order to put in place the rights of the plaintiff

Whereas, if an administrative contract, which violates the legitimate interests of a third party, is not yet concluded, a third party may require the public body to prohibit the performance of an administrative action (contract signing), which is necessary to protect the rights or interests of the plaintiff ${ }^{48}$.

\section{Features of Administrative and Judicial Appeals for Administrative Contracts}

\subsection{Appeal for public procurement procedures}

With regard to procurement procedures, the highest body that reviews the administrative appeal and makes administrative decisions for the procurement procedure is the Public Procurement Commission $(C P C)^{49}$. Final decisions are considered the decisions made by the appellate review body, which itself resolves the administrative conflict and does not return it for reconsideration to the lower body that initially issued the act, giving a final settlement to the case ${ }^{50}$. The appeal to the court against these decisions does not suspend the procurement procedures nor the contract signing or the execution of the contract concluded by the respective parties ${ }^{51}$. The question arises as to what the complainant (the non-successful bidder) will ask the court and to whom?:

- before the signing of the contract, it will be a lawsuit that will challenge the decision of the competent administrative body (of the contracting authority or the CPC). In this case, therefore, prior to the signing of the contract, the administrative and judicial appeal may be made in order that the respective administrative body may order the cancellation of the contract award procedure ${ }^{52}$.

- after the signing of the contract, article 64 of Law No.9643, date. 20.12.2006, foresees

\footnotetext{
47 Law no.49/2012 "On the organization and functioning of administrative courts and adjudication of administrative disputes", as amended, article 40, paragraph 1, letters " $d$ " and "dh".

${ }^{48}$ Idem., article 40, paragraph 1, letter "e".

${ }^{49}$ Law No.9643, date 20.11.2006 "On Public Procurement", as amended, article 19/1.

50 Sokol Sadushi, "E Drejta Administrative 2", Tiranë 2005, pg.193-194.

${ }^{51}$ Law No.9643, date. 20.11.2006 "On Public Procurement", as amended, article 64/3: "(1) The parties have the right to file a lawsuit for review of the administrative dispute against the decision of the Public Procurement Commission at the Tirana First Instance Administrative Court. (2) The examination of this appeal to the court does not suspend the procurement procedures, the conclusion of a public contract for the procurement of goods, services or works by the contracting authority or the execution of the obligations, according to the procurement contract by the respective parties".

52 Idem., article 64, paragraph 3.
} 
that: "(4). Upon the conclusion of the contract, when the CPC determines that a decision or action by the contracting authority is in contradiction with any of the provisions of this law, it is entitled ... to make a declarative decision under which the judicial power may compensate the complainant, which has suffered loss or damage as a result of the violation of this law". From this legal provision it results that the procurement law itself in its content, does not allow the cancellation of the procedures after the contract is concluded, by not allowing the administrative body to intervene in the related administrative contract as the above will continue to show the effects. Here, the exception is only the case when the procurement contract is absolutely void, as it contravenes a provision of the law. In this case, as we have explained above, from any interested party to obtain that contract, a finding of this invalidity may be required.

If we are not dealing with the absolute invalidity of the contract, which is explicitly provided by the law, the procurement contract will continue to be in force despite the violation of the e-auction procedures. Such a legal provision in our legislation, in line with the community one, serves the legal certainty and also the continuity of the performance of works, services and public supplies. Of course, it is guaranteed the right to claim compensation to the court for the damage sustained by the legal violations of the administration bodies in these proceedings. Regarding the claim for compensation of damage, we will have to do a claim for extra-contractual damage compensation according to the Civil Code ${ }^{53}$, which should be judged by the administrative court, as it relates to damages incurred by the enforcement of administrative acts.

\subsection{Judicial appeal in respect of administrative contracts}

Any dispute between the contracting parties, resulting from an administrative contract, is solved directly by the competent court for administrative issues ${ }^{54}$. The lawsuit that may be filed in any case is the lawsuit to be filed if we were in front of a private law contract. In addition to this legal basis, should be taken into the consideration the specific provisions of the public law, such as, for example, public procurement legislation.

If the administrative body intervenes unilaterally in the contract and the contracting party disagrees, then the above may be in front of the dilemma: to oppose the intrusive administrative act or to base its claims solely on the basis of the contract. The Supreme Court has established a consolidated practice by not accepting the protection of contractual rights by complaining about the act issued by the other party (administrative body), but based on the legal requirements for the protection of the contractual relationship between parties ${ }^{55}$.

As for third parties, our jurisprudence has been based on the view that the third party that has been damaged by an administrative contract cannot break this contract. In this case, the third may impinge the act/administrative acts that have led to the conclusion of the contract as unlawful public administration actions, seeking damages for the illegal actions of the administration for the incurred damage. However, in cases where the specific law itself provides for the absolute invalidity of the administrative contract, due to irregularities in the constitutional acts of the public contracting willpower, this invalidity (since it is of an absolute nature) may be required by any third interested person.

\section{Conclusions}

Administrative contracts are a sui generis type of contract, because the foundations of their legal regulation are in the private law and, in the same time, they are subject to specific arrangements of

${ }^{53}$ Civil Code, article 608 and following.

${ }^{54}$ C.A.P, article 125.

${ }^{55}$ Decision No.513, date 11.03.2003 of the Supreme Court: "..... In these circumstances, the plaintiff is not legitimated to challenge the administrative acts issued by the respondent body as in the present legal and factual situation the parties between them have contractual relations". 
the public law. In this way, the civil law is applied to the extent that it is not provided otherwise in these special regulations of public law. This dualistic nature of administrative contracts places opposite each other the two main principles of both private and public law. Freedom of contract willpower and equality of the parties shall apply to such contracts, as long as the principle of public interest protection, provided in the special administrative legislation, does not impose the dominance of the unilateral authority of a public body. The direct consequence of this nature is the fact that the necessary conditions for the connection and validity of the administrative contract are cumulatively found in Civil Code and C.A.P.

The direct consequence of the above conclusion is the fact that the violation of the public interest allows the administration to terminate the contractual relationship at any moment without being necessarily connected to the fact of execution or not of the contract by the other party. A unilateral termination for public interest purposes constitutes a discretionary power to the administration associated with its obligation to reward the other party. In special cases, the administration may change the size of the contract object by adding or reducing it, as earlier unforeseen contingencies are raised. Such a possibility is not unrestricted for the administration, as the public interest does not have to affect the financial interests of the other contracting party but the private party cannot protect its contractual rights by affecting the administrative act but only by seeking protection of the contractual relationship.

The collapse in contravention of an ordinate provision of the law is an invalidity clause which, in administrative contracts, is manifested in the case when the legal requirements governing the administrative procedures which precede the conclusion of an administrative contract have been violated. Thus, the law on specific contracts expressly provides the invalidity of the administrative contract ex lege if the interests of third parties are violated by this contract in the form of disrespect of the deadline and the administrative appeal procedure. In these cases, the absolute invalidity of administrative acts of the procurement phase may affect the validity of the procurement contract. For this reason, the third person to whom the interests have been violated, in addition to the compensation, may request to the administrative court the abrogation of the administrative act through which the public administration body has formed the willpower to conclude the administrative contract and as consequence the invalidity of the administrative contract itself.

The importance of protecting the public interest brings the limitation of the negotiating autonomy of the public body. This restriction is noticed in the fact that the public administration is not free to choose the other contracting party and the impossibility of the public administration body to set the terms of the administrative contract completely freely, which implies in some cases the imposition of predetermined contractual standards models.

\section{References}

Sokol Sadushi, "E drejta administrative", Tiranë 2005, Shtëpia Botuese ORA.

Sokol Sadushi, "E Drejta Administrative 2", Tiranë 2005.

André de Laubadére, Yves Gaudemet, "Traite dë droit administratif, Tome 2, Paris 1996, Le photocopillage Tue Le Livre".

Nicola Durante, "Arresti giurisprudenziali in tema di annullamento dell'aggiudicazione ed effetti sul contratto medio tempore stipulato".

Law No.44/2015 "Code of Administrative Procedures of the Republic of Albania ".

Law No.7491, date.29.04.1991 "For the main constitutional provisions".

Law No.8485, date.12.05.1999 "Code of Administrative Procedures".

Law No.9643, date 20.11.2006 "On Public Procurement", as amended.

Law No.9874, date 14.2.2008 "On Public Auction", as amended.

Law No. 9663, date 18.12.2006 "On Concessions", as amended.

Albanian Civil Code, article 663.

Law no.49/2012 "On the organization and functioning of administrative courts and adjudication of administrative disputes", as amended.

CMD Nr.914, date 29.12.2014 "On approval of public procurement rules", as amended.

Decision of the Supreme Court No.822, date 12.05.2005 ("Curri" I.I.c vs. Ministry of Culture, Youth and Sports).

Decision of the Supreme Court No.513, date 11.03.2003 (“Arberi” I.I.c vs. Municipality of Ballsh).

Decision No.7481, date 27 March 2007 of the "Corte Civile di Cassazione" Italy. 